\title{
POLA OSMOREGULASI, INDEKS PONDERAL, DAN KEMATANGAN GONAD KEPITING BAKAU (Scylla serrata) DI TAMBAK DESA PESANTREN, KECAMATAN ULUJAMI, PEMALANG
}

\author{
Osmoregulation Pattern, Ponderal Index, and Gonad Maturity of Mangrove Crab (Scylla serrata) in the \\ Pesantren Village Pond, Ulujami District, Pemalang
}

\author{
Anastia Afika Riza, Sutrisno Anggoro, Suryanti Suryanti \\ Program Studi Manajemen Sumberdaya Perairan \\ Departemen Sumberdaya Akuatik \\ Fakultas Perikanan dan Ilmu Kelautan,Universitas Diponegoro \\ Jl. Prof. Soedarto,SH Tembalang, Semarang \\ Email: anastiafika@gmail.com, sutrisnoanggoro52@gmail.com, suryantidr@gmail.com
}

Diserahkan tanggal 27 Juni 2019, Diterima tanggal 18 September 2019

\begin{abstract}
ABSTRAK
Osmoregulasi merupakan aspek yang sangat penting untuk diteliti dalam kegiatan budidaya kepiting bakau yang mana air media hidupnya kerap mengalami perubahan sifat fisika dan kimia. Salinitas memberikan pengaruh terhadap tekanan-tekanan osmotik yang berbeda terhadap tekanan osmotik tubuh organisme perairan, sehingga mengharuskan untuk melakukan proses osmoregulasi untuk menyeimbangkan tekanan osmotiknya. Tujuan dari penelitian ini adalah mengetahui tingkat kerja osmotik (TKO), indeks ponderal, dan kematangan gonad kepiting bakau serta hubungan TKO dengan indeks ponderal dan kematangan gonadnya. Penelitian dilakukan pada bulan Desember sampai Maret 2019. Materi utama yang dijadikan objek pengamatan adalah kepiting bakau yang dibudidaya di tambak Desa Pesantren Ulujami Pemalang. Metode penelitian yang digunakan adalah studi kasus menggunakan analisis deskriptif dan korelasi dengan pengambilan sampel menggunakan metode purposive sampling. Hasil penelitian menunjukkan kepiting bakau di tambak Desa Pesantren memiliki pola osmoregulasi hiperosmotik sedangkan pola osmoregulasi isoosmotik ditunjukkan pada kepiting yang sedang mengalami moulting. Indeks ponderal kurang dari dua sehingga bertubuh pipih dan belum matang gonad. Adapun tekanan osmotik berpengaruh negatif terhadap indeks ponderal dan kematangan gonad kepiting.
\end{abstract}

Kata kunci: Tingkat kerja osmotik; indeks ponderal; kematangan gonad; kepiting bakau

\section{ABSTRACT}

Osmoregulation as a very important aspect to be studied in the cultivation of mangrove crabs where pond water changes in physical and chemical properties. Salinity cause differences in the body's osmotic pressure and the osmotic pressure of pond water. This organism must carry out an osmoregulation process to balance its osmotic pressure. Thes purposes of this research were to determine the level of osmotic performance rates, ponderal index, the maturity of the gonads of mangrove crabs and the relationship between osmotic performance rates with ponderal index and maturity of the gonads. The research was conducted from November to March 2019, the animals used as objects of observation were mangrove crabs (Scylla serrata) that were cultivated in the Pesantren Village Pond, Ulujami District, Pemalang. This research used a case study method with descriptive analysis and correlation and sampling used the purposive sampling method. The research result showed that mangrove crabs in Pesantren. village ponds have hyperosmotic osmoregulation patterns while those that are moulting have an isoosmotic osmoregulation pattern. Ponderal index value of crabs was found less than two so that the body was flat and immature gonads. The osmotic pressure has a negative effect on the ponderal index and maturity of gonad crabs.

Keywords: Osmotic performance rates; ponderal index; maturity of gonad; mangrove crabs

\section{PENDAHULUAN}

Kepiting bakau merupakan salah satu komoditi penting di Indonesia. Kepiting bakau banyak diminati masyarakat untuk dikonsumsi karena memiliki cita rasa enak dan juga bergizi. Menurut Dirjen P2HP KKP tahun 2011 volume ekspor kepiting mencapai 23.089 ton. Permintaan pasar lokal maupun pasar internasional cenderung meningkat setiap tahunnya. Seiring dengan terus meningkatnya permintaan konsumen akan kepiting bakau terutama pasar internasional mengharuskan upaya produksi kepiting bakau secara budidaya intensif. Hal ini dilakukan mengingat produksi penangkapan dari alam semakin menurun karena rusaknya habitas aslinya yaitu hutan mangrove.

Salah satu daerah yang sudah menerapkan budidaya kepiting adalah Kecamatan Ulujami Pemalang termasuk di Desa Pesantren. Kecamatan Ulujami merupakan salah satu sentra produksi kepiting di Kabupaten Pemalang. Untuk menunjang keberhasilan budidaya kepiting yang ditandai dengan pertumbuhan yang pesat dan mortalitas yang rendah, 
diperlukan pengaturan kualitas air media yang optimum. Salah satunya yaitu salinitas yang isoosmotik.

Menurut Pamungkas (2012), salinitas adalah konsentrasi seluruh larutan garam yang terlarut dalam air. Salinitas merupakan masking faktor yang mana keberadaannya didalam tambak menimbulkan tekanantekanan osmotik yang berbeda dengan tekanan osmotik tubuh organisme. Lebih lanjut dijelaskan oleh Anggoro (2000) kisaran salinitas yang efektif untuk kegiatan budidaya bervariasi tergantung dari spesies, umur dan faktor lingkungan lainnya seperti temperatur. Organisme yang berada pada kondisi dimana tekanan osmotik medianya berbeda dengan tubuhnya akan melakukan mekanisme pengaturan osmosis agar mencapai kesetimbangan osmotik tubuh dan lingkungannya. Mekanisme pengaturan osmotik didalam tubuh disebut dengan osmoregulasi.

Menurut Puryono et al. (2019), osmoregulasi merupakan suatu sistem homeostasis untuk menyeimbangkan kemantapan millieu interiueur-nya dengan cara mengatur keseimbangan konsentrasi osmotik cairan intrasel dengan cairan ekstraselnya. Salinitas sangat berpengaruh terhadap proses osmoregulasi. Apabila salinitas media berada jauh dari kondisi isoosmotik maka proses osmoregulasi akan berlangsung lebih berat sehingga menyerap banyak energi yang kemudian akan berdampak pada menurunnya laju pertumbuhan dan perkembangannya. Mengingat pentingnya hal tersebut maka sangat diperlukan penelitian mengenai proses osmoregulasi kepiting bakau.

Hingga saat ini, belum pernah dilakukan penelitian mengenai pola osmoregulasi kepiting di Desa Pesantren maupun di Kecamatan Ulujami. Penelitian yang sudah dilakukan hanya sebatas mengkaji karakteristik biometrika kepiting bakau, kajian produksi udang vannamei, dan kualitas perairan berdasarkan parameter fisika dan kimianya. Sehingga sangat diperlukan penelitian mengenai pola osmoregulasi kepiting bakau untuk menemukan kisaran salinitas air tambak yang isoosmotik sehingga mampu meningkatkan produksi kepiting bakau.

Tujuan dilakukannya penelitian ini adalah untuk mengetahui tingkat kerja osmotik (TKO), indeks ponderal, dan kematangan gonad serta hubungan antara TKO dengan dan kematangan gonad. Hasil penelitian ini diharapkan dapat menghasilkan informasi tentang respon fisiologi sistem osmoregulasi kepiting khususnya di tambak kepiting Desa Pesantren Kecamatan Ulujami Pemalang. Selain itu, juga diharapkan dapat menjadi informasi dasar kepada pembudidaya kepiting bakau untuk menerapkan kualitas air yang ideal terutama kisaran salinitas yang isoosmotik didalam meningkatkan pertumbuhan dan kelangsungan hidup kepiting bakau. khususnya di tambak kepiting Desa Pesantren Kecamatan Ulujami Pemalang. Penelitian ini juga diharapkan dapat menjadi informasi dasar kepada pembudidaya kepiting bakau untuk menerapkan kualitas air yang ideal terutama kisaran salinitas yang isoosmotik didalam meningkatkan pertumbuhan dan kelangsungan hidup kepiting bakau.

\section{METODE PENELITIAN}

Materi yang digunakan dalam penelitian ini adalah kepiting bakau jenis Scylla serrata dan air tambak yang diambil pada bulan Desember 2018 dan Maret 2017. Sedangkan alat yang digunakan dalam penelitian ini adalah
Automatic Osmometer Roebling, timbangan elektrik, jangka sorong, refraktometer, botol PE, microtube, spuit suntik, termometer, $\mathrm{pH}$ paper, cool box, alat sectio, dan komputer.

\section{Metode}

Metode penelitian yang digunakan adalah studi kasus dengan pendekatan analisis deskriptif dan analisis korelasi. Menurut Hasan (2002), studi kasus merupakan suatu pendekatan yang Studi kasus dengan analisis deskriptif mempelajari objek secara mendalam pada waktu, tempat dan populasi terbatas. Adapun yang damati dalam penelitian ini adalah tingkat kerja osmotik, indeks ponderal, kematangan gonad kepiting, dan kualitas perairan yang meliputi salinitas, temperatur, dan $\mathrm{pH}$. Dijelanjaskan lebih lanjut oleh Hasan (2002), analisis korelasi dilakukan untuk mengetahui hubungan dan tingkat hubungan antar dua variabel atau lebih tanpa mempengaruhi variabel tersebut. Analisis korelasi digunakan untuk mengetahui hubungan TKO dengan indeks ponderal dan tingkat kematangan gonad (TKG) atau indeks kematangan gonad (IKG) kepiting bakau. Pengambilan sampel dilakukan dengan menggunakan metode purposive sampling yaitu teknik pengambilan sampel yang didasarkan pada pertimbangan tertentu (Fachrul, 2007).

\section{Teknik Pengambilan Sampel}

Sampel kepiting yang diambil merupakan kepiting yang dibudidayakan pada tambak kepiting soka di Desa Pesantren, Ulujami Pemalang. Terdapat dua tambak atau stasiun yang dijadikan lokasi penelitian.

Data yang diambil meliputi osmolaritas haemolymph kepiting, osmolaritas darah, pengukuran bobot dan lebar karapas, TKG dan IKG, serta kualitas air. Jumlah kepiting yang dijadikan pengamatan indeks ponderal berjumlah 80 ekor, untuk pengukuran osmolaritas sebanyak 15 ekor dimana 10 ekor diambil pada stasiun I dan 5 ekor diambil pada stasiun II. Sedangkan untuk pengamatan TKG dan IKG berjumlah 15 ekor kepiting.

Pengukuran lebar karapas menggunakan jangka sorong dengan ketelitian $0.1 \mathrm{~mm}$ dan bobot menggunakan timbangan elektrik dengan ketelitian 0,1 gr. Air media danhaemolymph yang diukur osmolaritasnya diambil menggunakan spuit suntik ukuran $23 \mathrm{G}$ dan dimasukkan kedalam microtube sebanyak $0,1 \mathrm{ml}$. Pengukuran osmolaritas haemolymph dan osmolaritas media menggunakan bantuan alat Automatic Micro-osmometer roebling Type 13/13 DR Autocal.

\section{Tingkat Kerja Osmotik}

Pengamatan kerja osmotik dilakukan dengan mengukur osmolaritas haemolymph dan osmolaritas air media menggunakan alat Automatic Osmometer roebling. Tingkat kerja osmotik dapat diketahui menggunakan rumus (Anggoro dan Nakamura, 2005) :

$\mathrm{TKO}=(\mathrm{P}$ osmo haemolymph $-\mathrm{P}$ osmo media $)$

Dimana: $\mathrm{TKO}=$ tingkat kerja osmotik $\left(\mathrm{mOsm} / \mathrm{I} \mathrm{H}_{2} \mathrm{O}\right) ; \quad \mathrm{P}$ osmo haemolymph $=$ tekanan osmotik cairan tubuh $(\mathrm{mOsm} / \mathrm{I}$ $\left.\mathrm{H}_{2} \mathrm{O}\right) ; \quad \mathrm{P}$ osmo media = tekanan osmotik media $(\mathrm{mOsm} / \mathrm{I}$ $\mathrm{H}_{2} \mathrm{O}$ )

Setelah diketahui osmolaritas dan nilai tekanan osmotik kepiting bakau, kemudian dikonfersi untuk mengetahui 
kisaran salinitas air media yang isoosmotik menggunakan persamaan Anggoro (1992), sebagai berikut :

$$
0 \mathrm{sm}=-5,4081+29,3489 \mathrm{~S}
$$

Keterangan $: 0 \mathrm{sm}=$ Osmolaritas biota $; \mathrm{S}=$ Salinitas

\section{Indeks Ponderal}

Analisis indeks ponderal, terlebih dahulu dilakukan perhitungan hubungan lebar karapas dengan bobot kepiting. Hubungan lebar karapas dihitung dengan menggunakan Effendi (2002)

$$
\mathrm{W}=\mathrm{a} \mathrm{L}^{\mathrm{b}}
$$

Dimana $\mathrm{W}=$ bobot kepiting (gram), L adalah lebar karapas (cm), $a$ dan $b$ adalah konstanta. Jika nilai $b=3$ Pertumbuhan kepiting bersifat isometrik sedangkan jika nilai $b \neq 3$ maka pertumbuhan bersifat allometrik. Apabila pertumbuhan bersifat isometrik pengukuran indeks ponderal menggunakan persamaan $\mathrm{K}=10 \mathrm{~W} / \mathrm{L}^{3}$. Namun jika pertumbuhan bersifat allometrik indeks ponderal menggunakan persamaan Effendie (2002).

$$
\mathrm{K}=\mathrm{W} / \mathrm{aL}
$$

Dimana: $\mathrm{K}=$ indeks ponderal; $\mathrm{W}=$ bobot kepiting (gram); $\mathrm{L}=$ lebar karapas (cm).

\section{TKG dan IKG}

Penentuan tingkat kematangan gonad (TKG) kepiting dilakukan klasifikasi tahapan TKG kepiting. Adapun tahapan TKG menurut Aisyah et al. (2018) terdapat dalam Tabel 1. Sedangkan IKG dihitung menggunakan persamaan Effendi, (2002):

$$
\text { IKG }(\%)=\frac{w G}{w} \times \mathbf{1 0 0} \%
$$

\begin{tabular}{|c|c|c|}
\hline Stadium & Ciri Morfologi & Gambar Stage \\
\hline I & $\begin{array}{l}\text { Gonad berwarna putih } \\
\text { hingga krem. Gonad } \\
\text { seprti garis pita lobula } \\
\text { mulai berkembang }\end{array}$ & \\
\hline II & $\begin{array}{l}\text { Gonad berwarna krem } \\
\text { oranye. Ovari mulai } \\
\text { berkembang dan } \\
\text { ukuran ovarium } \\
\text { bertambah. Butir telur } \\
\text { belum terlihat }\end{array}$ & \\
\hline III & $\begin{array}{l}\text { Gonad berwarna } \\
\text { kuning ingga oranye. } \\
\text { Ovarium bertambah } \\
\text { besar butiran telur } \\
\text { mulai terlihat namun } \\
\text { masih terlapisi oleh } \\
\text { kelenjar minyak }\end{array}$ & \\
\hline IV & $\begin{array}{l}\text { Gonad berwarna merah } \\
\text { oranye. Ovarium } \\
\text { hampir mengisi seluruh } \\
\text { rongga dada. Butiran } \\
\text { telur dapat terlihat oleh } \\
\text { mata. }\end{array}$ & \\
\hline
\end{tabular}

Dimana: $\mathrm{IKG}=$ indeks kematangan gonad; $\mathrm{Wg}=$ berat gonad; $\mathrm{W}=$ berat tubuh.

Tabel 1. Klasifikasi TKG Kepiting Bakau

\section{HASIL DAN PEMBAHASAN}

Hasil

Pola osmoregulasi dan Tingkat Kerja Osmotik (TKO)

Hasil dari pengukuran osmolaritas haemolymph kepiting dan osmolaritas media diperoleh nilai TKO dan pola osmoregulasi kepiting yang dapat dilihat pada Tabel 2 . Setelah diketahui osmolaritas kepiting bakau, kemudian dihitung kisaran salinitas air media yang isoosmotik menggunakan persamaan hubungan osmolaritas dan salinitas. Adapun kisaran salinitas yang isoosmotik tersaji pada Tabel 3.

Tabel 3 menunjukkan kisaran salinitas air media yang isoosmotik bervariasi antar individu kepiting meskipun perbedaannya tidak terlalu lebar. Kisaran salinitas yang isoosmotik bagi kepiting bakau adalah $29,91 \%-30,25 \%$

Tabel 3. Kisaran Media yang Isoosmotik Bagi Kepiting Bakau

\begin{tabular}{ccc}
\hline $\begin{array}{c}\text { Osmolaritas Kepiting } \\
\left(\mathrm{mOsm} / \mathrm{I} \mathrm{H}_{2} \mathrm{O}\right)\end{array}$ & $\begin{array}{c}\text { Salinitas } \\
(\%)\end{array}$ & $\begin{array}{c}\text { Salinitas yang } \\
\text { Isoosmotik }\end{array}$ \\
\hline 878,7 & 14 & 30,12 \\
880,3 & 14 & 30,17 \\
880,3 & 14 & 30,17 \\
872,7 & 14 & 29,91 \\
875,7 & 14 & 30,02 \\
876,0 & 20 & 30,03 \\
878,0 & 20 & 30,10 \\
882,7 & 20 & 30,25 \\
878,7 & 20 & 30,12 \\
877,3 & 20 & 30,07 \\
\hline
\end{tabular}

Analisis Hubungan Panjang Berat dan Indeks Ponderal

Grafik hubungan panjang berat kepiting di stasiun I dan stasiun II dapat dilihat pada Gambar 1 dan 2. Setelah dilakukannya perhitungan hubungan lebar karapas dengan bobot kepiting bakau, kemudian dilanjutkan dengan perhitungan indeks ponderal. Dari perhitungan yang telah dilakukan, didapatkan hasil rata-rata indeks ponderal di stasiun I sebesar 1,003 dan stasiun II sebesar 1,017.

\section{TKG, IKG, dan Osmolaritas Gonad}

Hasil pengamatan TKG kepiting bakau tertera pada Gambar 3 dan 4. Sedangkan IKG tertera pada gambar 5.

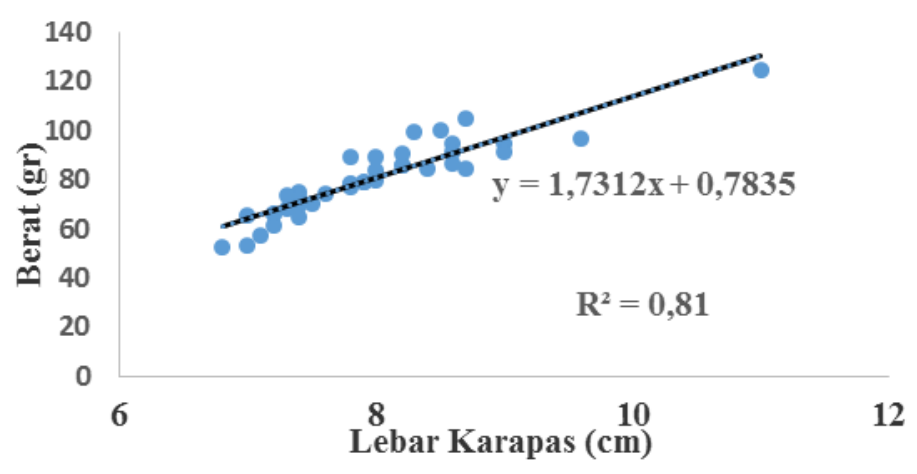

Gambar 1. Grafik hubungan lebar karapas dan berat kepiting di stasiun I 
Tabel 2. Nilai Osmolaritas Haemolymph Kepiting, Osmolaritas Media dan TKO Kepiting Bakau

\begin{tabular}{|c|c|c|c|c|c|c|}
\hline \multirow[t]{2}{*}{ Stasiun } & \multirow[t]{2}{*}{$\begin{array}{c}\text { Sampel } \\
\text { Kepiting }\end{array}$} & \multirow[t]{2}{*}{$\begin{array}{l}\text { Salinitas } \\
\quad(\%)\end{array}$} & \multicolumn{2}{|c|}{$\begin{array}{c}\text { Osmolaritas } \\
\left(\mathrm{mOsm} / \mathrm{I} \mathrm{H}_{2} \mathrm{O}\right)\end{array}$} & \multirow{2}{*}{$\begin{array}{c}\text { TKO } \\
(\mathrm{mOsm} / \\
\left.\mathrm{I} \mathrm{H}_{2} \mathrm{O}\right) \\
\end{array}$} & \multirow[t]{2}{*}{$\begin{array}{c}\text { Pola } \\
\text { Osmoregulas }\end{array}$} \\
\hline & & & Haemolymph & Media & & \\
\hline \multirow{12}{*}{ I } & I & 6 & 878,7 & 823,7 & 55,0 & Hiperosmotik \\
\hline & II & 6 & 880,3 & 826,0 & 54,3 & Hiperosmotik \\
\hline & III & 6 & 880,3 & 830,3 & 50,0 & Hiperosmotik \\
\hline & IV & 6 & 872,7 & 834,0 & 38,7 & Hiperosmotik \\
\hline & $\mathrm{V}$ & 6 & 875,7 & 826,2 & 49,5 & Hiperosmotik \\
\hline & Rata-rata & 6 & 877,5 & 828,0 & 49,5 & Hiperosmotik \\
\hline & Moulting I & 6 & 822 & 824,8 & $-2,8$ & Isoosmotik \\
\hline & Moulting II & 6 & 822,7 & 819,3 & 3,4 & Isoosmotik \\
\hline & Moulting III & 6 & 823 & 820,4 & 2,6 & Isoosmotik \\
\hline & Moulting IV & 6 & 822 & 820 & 2,0 & Isoosmotik \\
\hline & Moulting V & 6 & 821 & 819 & 2,0 & Isoosmotik \\
\hline & Rata-rata & 6 & 822,14 & 820,7 & 1,4 & Isoosmotik \\
\hline \multirow{6}{*}{ II } & I & 11 & 876,0 & 840,0 & 36,0 & Hiperosmotik \\
\hline & II & 11 & 878,0 & 846,0 & 32,0 & Hiperosmotik \\
\hline & III & 11 & 882,7 & 841,7 & 41,0 & Hiperosmotik \\
\hline & IV & 11 & 878,7 & 845,0 & 33,7 & Hiperosmotik \\
\hline & $\mathrm{V}$ & 11 & 877,3 & 847,3 & 30,0 & Hiperosmotik \\
\hline & Rata-rata & 11 & 878,5 & 844,0 & 34,5 & Hiperosmotik \\
\hline
\end{tabular}

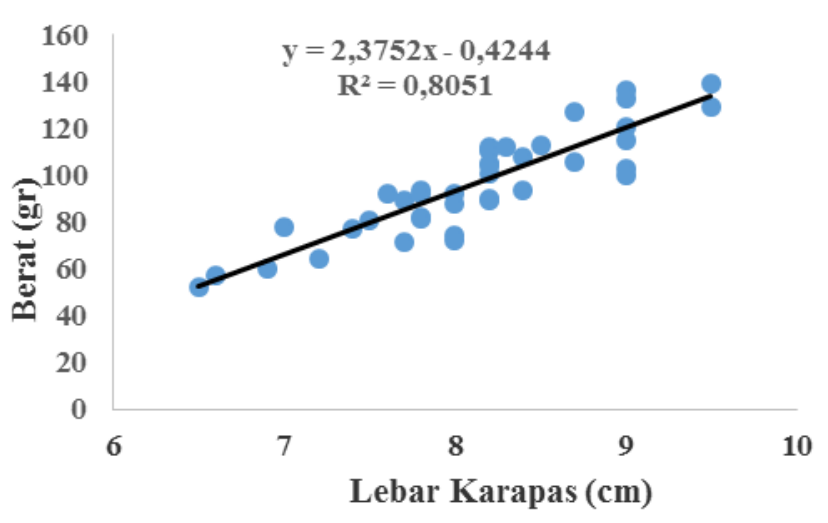

Gambar 2. Grafik hubungan lebar karapas dan berat kepiting bakau pada stasiun II

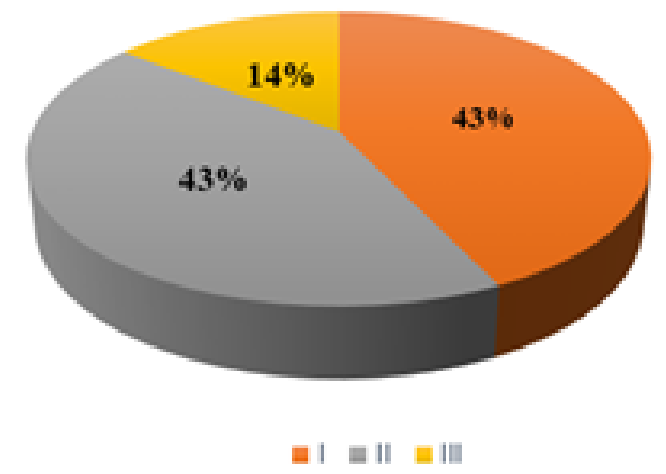

Gambar 3. TKG Kepiting Jantan

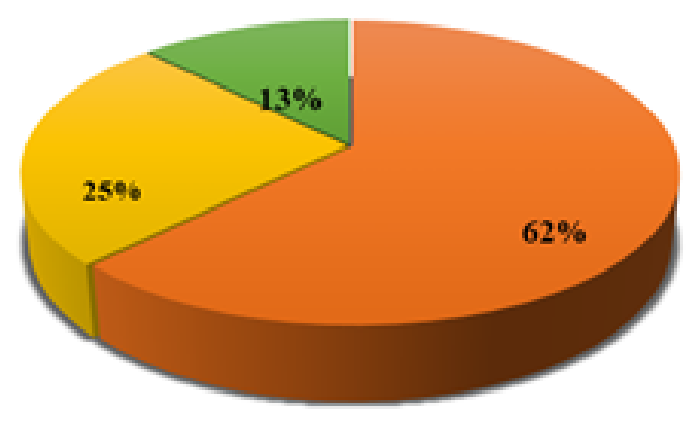

EI $=11=|1|$

Gambar 4. TKG Kepiting Betina

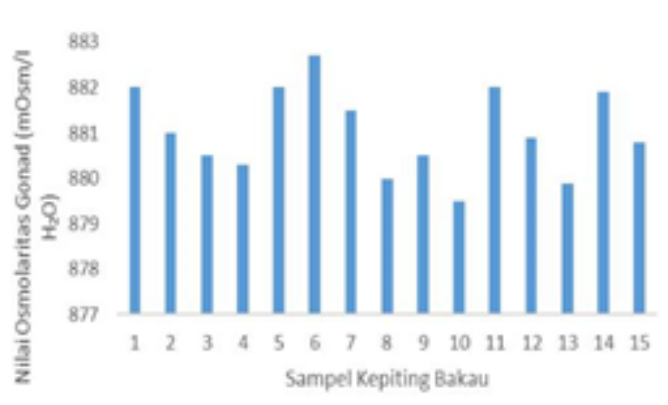

Gambar 5. Osmolaritas Gonad Kepitig

\footnotetext{
C Copyright by Saintek Perikanan: Indonesian Journal of Fisheries Science and Technology, ISSN : 1858-4748
} 


\section{Hubungan TKO dengan indeks ponderal dan IKG serta hubungan osmolaritas gonad dengan IKG}

Hubungan TKO dengan indeks ponderal dan IKG tersaji pada gambar 6,7,8 dan 9

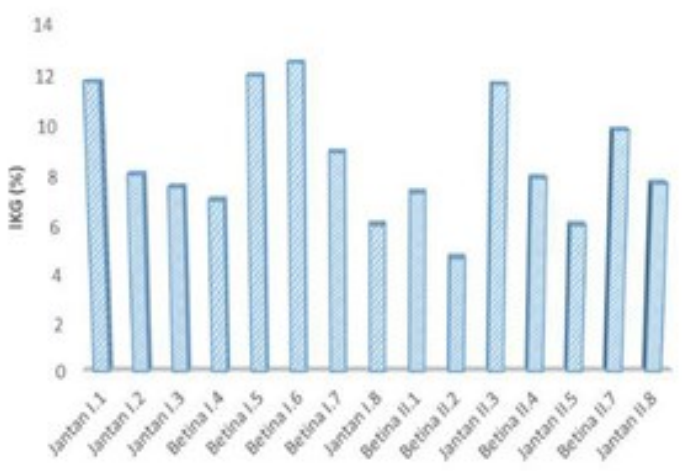

Gambar 6. IKG Kepiting Bakau (Scylla serrata)

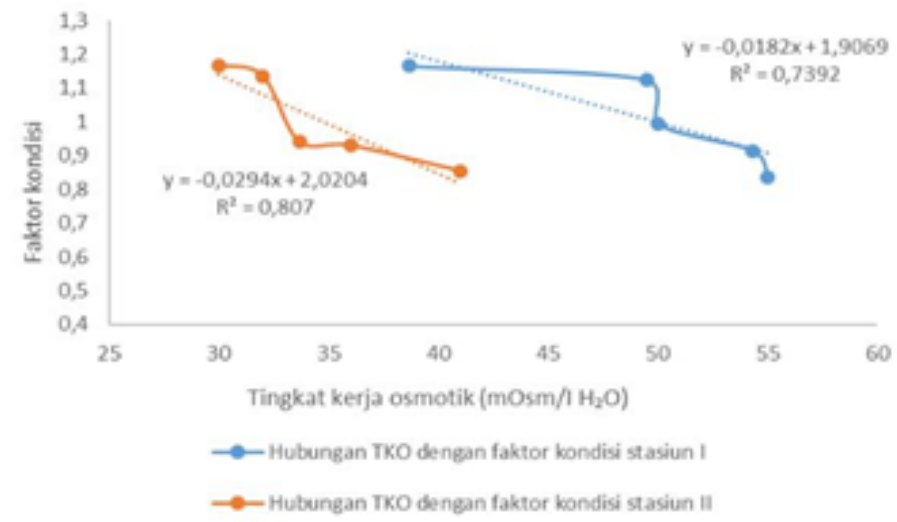

Gambar 7. Hubungan TKO kepiting dengan indeks pondera

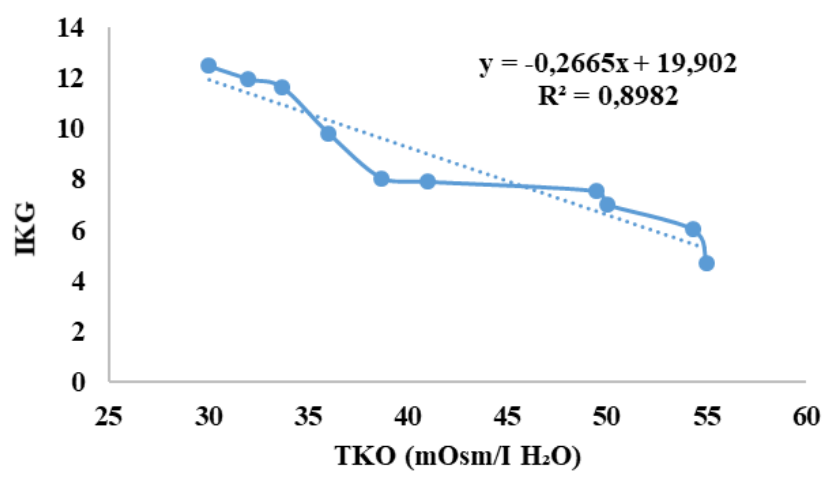

Gambar 8. Hubungan TKO Kepiting dengan IKG

Hubungan TKO dengan Indeks Ponderal dan IKG Menunjukkan Pola Linier Bersifat Negatif. Terlihat pada grafik, semakin besar nilai TKO maka nilai indeks ponderal dan IKG akan semakin kecil

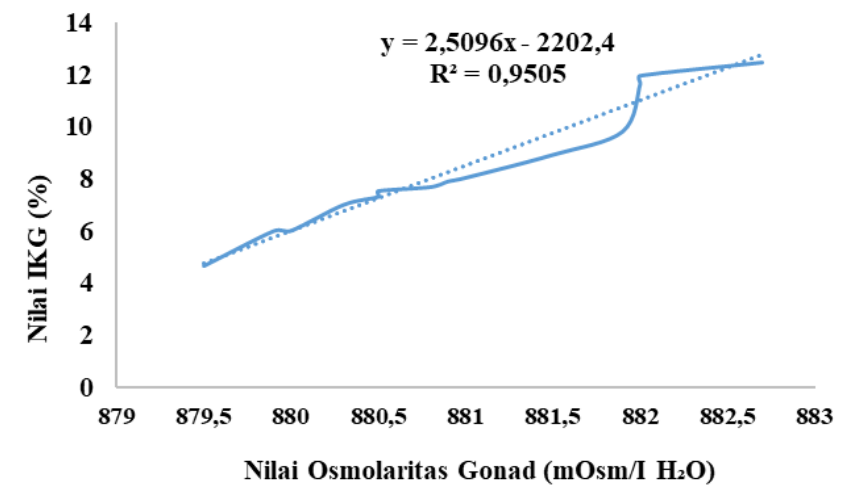

Gambar 9. Hubungan osmolaritas gonad dengan IKG

Hubungan osmolaritas gonad dengan IKG linier besifat positif. Kenaikan osmolaritas gonad diikuti dengan kenaikan IKG.

\section{Kualitas air}

Pengukuran kualitas air meliputi variabel salinitas, temperatur, dan ph. Hasil pengukuran kualitas air dapat dilihat pada Tabel 4.

Tabel 4. Data Pengamatan Kualitas Air Tambak

\begin{tabular}{llccc}
\hline \multirow{2}{*}{ No } & \multirow{2}{*}{ Parameter } & \multicolumn{2}{c}{ Nilai Pengamatan } & Nilai \\
\cline { 3 - 4 } & & Stasiun I & Stasiun II & \\
\hline 1 & Salinitas (\%) & 6 & 11 & $* 10-35$ \\
2 & Temperatur ( C) & 33 & 33 & $* * 23-33$ \\
3 & $\mathrm{pH}$ & 8 & 8 & $* * 6,5-9$ \\
\hline
\end{tabular}

Keterangan :

*FAO $2011 \quad * *$ Katiandagho (2014)

\section{Pembahasan}

\section{Tingkat Kerja Osmotik}

Hasil penelitian diketahui jika salinitas air tambak di stasiun I bernilai $11 \mathrm{ppt}$ dan mempunyai osmolaritas media berkisar 832,7 mOsm/ $\mathrm{I} \mathrm{H}_{2} \mathrm{O}$ hingga 834,0 mOsm/ $\mathrm{I} \mathrm{H}_{2} \mathrm{O}$. Sedangkan osmolaritas haemolymph kepiting berkisar antara $872,7 \mathrm{mOsm} / \mathrm{I} \quad \mathrm{H}_{2} \mathrm{O}$ hingga $880,3 \mathrm{mOsm} / \mathrm{I} \mathrm{H}_{2} \mathrm{O}$. Dari pengukuran osmolaritas tersebut diperoleh tingkat kerja osmotik sebesar 38,7 mOsm/ $\mathrm{I} \mathrm{H}_{2} \mathrm{O}$ hingga 55,0 mOsm/I $\mathrm{H}_{2} \mathrm{O}$. Nilai osmolaritas air media lebih rendah dibandingkan dengan osmolaritas haemolymph sehingga kepiting bakau memiliki pola osmoregulasi hiperosmotik. Sesuai dengan pernyataan Novian et al. (2013) yaitu regulasi hiperosmotik terjadi saat kondisi osmolaritas darah lebih tinggi dibandingkan dengan osmolaritas media hidupnya.

Air tambak pada stasiun II memiliki salinitas sebesar 20 ppt dengan nilai osmolaritas air medianya sebesar 840,0 $\mathrm{mOsm} / \mathrm{I} \quad \mathrm{H}_{2} \mathrm{O}$ hingga 847,3 $\mathrm{mOsm} / \mathrm{I} \quad \mathrm{H}_{2} \mathrm{O}$. Sedangkan osmolaritas haemolymph kepiting bervariasi sebesar 876,0 mOsm/ $/ \mathrm{H}_{2} \mathrm{O}$ hingga $882,7 \mathrm{mOsm} / \mathrm{I} \mathrm{H}_{2} \mathrm{O}$ sehingga kepiting memiliki pola osmoregulasi hipertonik dengan rata-rata tingkat kerja osmotik sebesar 34,5 mOsm/ $/ \mathrm{H}_{2} \mathrm{O}$.

\footnotetext{
(C) Copyright by Saintek Perikanan: Indonesian Journal of Fisheries Science and Technology, ISSN : 1858-4748
} 
Perbedaan TKO antara stasiun I dan stasiun II karena perbedaan salinitas air tambaknya. Pada stasiun I salinitas air hanya sebesar 11 ppt. Angka tersebut bukanlah salinitas optimal yang diperuntukkan untuk budidaya kepiting. Akibatnya, omolaritas air medianya jauh dibawah osmolaritas haemolymph kepiting sehingga menyebabkan tingkat kerja osmotik yang besar. Rachmawati et al. (2012) menyatakan tinggi rendahnya salinitas berpengaruh pada tekanan osmotik air. Kenaikan salinitas akan diikuti dengan kenaikan tekanan osmotiknya. Hal ini dikarenakan banyaknya ion $\mathrm{Na}^{+}$dan $\mathrm{Cl}^{-}$ yang terkandung dalam air. $\mathrm{Na}^{+}$dan $\mathrm{Cl}^{-}$merupakan ion-ion yang dominan menentukan nilai tekanan osmotik perairan. Dijelaskan lebih lanjut oleh Anggoro (2000), salinitas air dari media isoosmotik sangat berpengaruh terhadap tinggi rendahnya tingkat kerja osmotik untuk mencapai keadaan yang seimbang baik tekanan osmotik maupun kandungan elektrolit, sehingga apabila tingkat kerja osmotik tingi maka akan menyerap energi yang besar untui melakukan proses osmoregulasi.

Dalam kondisi hiperosmotik, kepiting akan melakukan proses osmoregulasi menjaga kemantapan osmolaritasnya dengan cara meningkatkan absorpsi ion garam dan air media melalui insang dan usus. Kemudian kepiting akan menghasilkan urine yang bersifat hipoosmotik (Puryono et al., 2019). Pada saat kepiting memiliki tingkat kerja osmotik yang besar, proses fisiologi lainnya seperti pertumbuhan dan reproduksi akan terganggu.

Kepiting yang sedang mengalami proses moulting cenderung memiliki pola osmoregulasi yang isoosmotik dengan tingkat kerja osmotik sebesar $2 \mathrm{mOsm} / \mathrm{I} \mathrm{H}_{2} \mathrm{O}$ hingga $3,4 \mathrm{mOsm} / \mathrm{I} \mathrm{H}_{2} \mathrm{O}$. Pola osmoregulasi yang isoosmotik terjadi akibat dari adanya perubahan sifat osmoregulasi kepiting pada saat moulting dari osmoregulator menjadi osmokonformer. Menurut Purnama et al. (2016), pada saat kepiting mengalami proses moulting, organ $\mathrm{X}$ akan berhenti bekerja dan hormon $\mathrm{MIH}$ (Molt inhibity hormone) tidak disekresikan sehingga memicu organ $\mathrm{Y}$ untuk memroduksi hormon MAH (Molt accelerating hormone) yang berfungsi mempercepat proses moulting

Hasil pengukuran kualitas perairan menunjukkan kondisi temperatur dan $\mathrm{pH}$ perairan masih dalam kondisi optimum. Salinitas media pada stasiun I bernilai $11 \%$ atau dibawah angka optimum untuk budidaya kepiting. Kondisi tersebut dapat mengganggu metabolisme kepiting jika tidak dilakukan pengaturan salinitas media yang optimum.

\section{Indeks Ponderal}

Berdasarkan pada gambar 1 dan 2 diketahui persamaan lebar karapas dan beratnya adalah $W=2,189 L^{1,7312}$ pada stasiun $I$ dan $W=0.6541 L^{2,3752}$ pada stasiun II. Nilai b pada stasiun I maupun II kurang dari 3 yang menunjukkan pola pertumbuhan kepiting bakau di Desa Pesantren bersifat allometrik negatif. Hal tersebut sama dengan penelitian yang dilakukan Sentosa dan Syam (2011), jika kepiting bakau yang ditangkap di Pantai Mayangan Subang yang juga terletak di Pantai Utara Jawa memiliki pertumbuhan allometrik negatif.

Nilai koefisien korelasi pada stasiun I sebesar 0,81 atau $81 \%$ pertambahan bobot kepiting terjadi karena pertambahan panjang tubuhnya. Sedangkan pada stasiun II koefisien korelasi sebesar 0,8051 atau $80,5 \%$ pertambahan bobot kepiting dipengaruhi karena pertambahan panjang tubuhnya.
Diluar dari itu pertambahan berat dipengaruhi oleh faktor lain seperti kualitas air dll. Menurut Hidayat et al. (2017), perbedaan laju pertumbuhan pada biota dipengaruhi oleh faktor internal yang meliputi genetik dan fisiologisnya serta faktor eksternal yang paling berpengaruh adalah kondisi lingkungan dan tinteraksi (kompetisi dan predasi).

Hasil analisis nilai rata-rata indeks ponderal (K) kepiting bakau pada tambak I adalah 1,003 sedangkan rata-rata indeks ponderal di tambak II adalah 1,017. Hal ini menunjukkan jika kepiting yang dibudidayakan di tambak Desa Pesantren memiliki bentuk tubuh yang pipih. Rendahnya nilai indeks ponderal pada kepiting dikarenakan kepiting yang dibudiaya masih muda dan belum matang gonad. Menurut Effendie (2002), variasi nilai $\mathrm{Kn}$ (indeks ponderal) tergantung dari umur, jenis kelamin, makanan dan kematangan gonad. Dijelaskan lebih lanjut oleh Bidawi et al. (2017), faktor kondisi dipengaruhi perkembangan gonadnya. Faktor kondisi akan meningkat pada fase ikan siap memijah.

Selain faktor umur dan kematangan gonad, rendahnya indeks ponderal juga disebabkan karena tingginya tingkat kerja osmotik. Analisis regresi korelasi menunjukkan bahwa hubungan TKO dengan indeks ponderal yaitu linier bersifat negatif. Semakin besar TKO, maka energi yang dibutuhkan untuk proses osmoregulasi semakin besar sehingga porsi energi untuk pertumbuhan berkurang. Menurut Pamungkas (2012), TKO mempengaruhi proses fisiologi hewan seperti pertumbuhan, kebiasaan makan, tingkah laku, dan reproduksi. Semakin besar TKO maka akan menghambat laju pertumbuhan biota. Hal ini berkaitan dengan penggunaan energi. Apabila energi yang digunakan biota untuk melakukan aktivitas osmoregulasi meningkat akibat dari tingginya nilai TKO, maka jumlah energi yang dipakai untuk pertumbuhan akan berkurang sehingga menurunkan laju pertumbuhan.

\section{TKG dan IKG}

Hasil pengamatan gonad menunjukkan jika kepiting bakau sebagian besar berada dalam tahap TKG I dan TKG II yang berarti belum memasuki tahap matang gonad. Hanya terdapat 1 kepiting yang berada dalam tahap TKG III. Seiring dengan belum matangnya gonad, nilai IKG kepiting juga cenderung kecil yaitu hanya berkisar 4,67\% - 12,4\%. Menurut Rahardja et al. (2011), dalam perkembangannya menuju matang goand, testis akan bertambah berat. Bobot testis bisa mencapai lebih dari $12 \%$ bobot tubuhnya, sedangkan ovarium akan bertambah besar mencapai puluhan persen bobot tubuhnya.

Belum matangnya gonad kepiting bakau di Tambak Desa Pesantren disebabkan oleh beberapa hal seperti kualitas perairan yang buruk khususnya salinitas yang rendah dan juga ketersediaan nutrien yang terbatas. Menurut Habibi et al. (2013), terdapat dua faktor yang memepengaruhi tingkat kematangan gonad yaitu faktor intrinsik yang meliputi umur, hormon, jenis ikan dan faktor ekstrinsik seperti makanan, kualitas perairan, dan intensitas cahaya.

Kecilnya TKG dan IKG kepiting juga disebabkan karena tekanan osmotik media yang tidak dalam kondisi isoosmotik. Tingginya TKO yang dialami kepiting menambah tingkat kerja enzim Na- K- ATP serta pengangkutan aktif ion $\mathrm{Na}^{+}$dan $\mathrm{CL}^{-}$. Akibatnya, energi yang digunakan untuk proses osmoregulasi bertambah sedangkan porsi energi untuk proses reproduksi berkurang. Hal ini sesuai dengan pernyataan 
Anggoro (2000), variasi salinitas lingkungan mengakibatkan ikan menggunakan banyak energinya untuk melakukan proses osmoregulasi mengatur tekanan osmotiknya agar seimbang dengan tekanan osmotik media. Besarnya energi yang digunakan tergantung pada besarnya nilai TKO dan kemampuan biota dalam melakukan penyesuaian diri dengan lingkungannya serta besarnya energi yang masuk dalam tubuh ikan. Kondisi tersebut menyebabkan terhambatnya laju pertumbuhan dan mengganggu proses reproduksi.

Osmolaritas gonad memiliki hubungan linier yang positif terhadap IKG. Osmolaritas gonad berkaitan erat dengan proses vitelogenesis atau pembentukan kuning telur. Semakin tinggi osmolaritas gonad akan menyebabkan cairan dari ekstra sel memasuki sel telur sehingga sel telur mengalami kenaikan volume dan memacu terjadinya penetasan telur. Menurut Darwasito et al. (2015), proses vitelogenesis dicirikan dengan bertambah banyaknya volume sitoplasma yang berasal dari luar sel sehingga sel telur menjadi lebih pekat. Oleh karena itu kualitas telur ditentukan saat proses vitelogenesis berlangsung. Beberapa faktor kualitas air khususnya salinitas dan aktivitas hormon sangat berperan untuk menunjang keberhasilan proses tersebut.

\section{KESIMPULAN}

Kepiting bakau di Desa Pesantren memiliki pola osmoregulasi hiperosmotik. Adapun kepiting yang sedang mengalami moulting memiliki pola osmoregulasi isoosmotik. Pada saat moulting, sifat osmoregulasi kepiting berubah dari osmoregulator menjadi osmokonformer. Kepiting bakau memiliki pola pertumbuhan allometrik negatif dengan indeks ponderal berkisar 1-2 . Sebagian besar kepiting yang dibudidaya di tambak Desa Pesantren masih dalam tahap belum matang gonad. Tingkat kerja osmotik (TKO) memiliki hubungan linier yang bersifat negatif terhadap pertumbuhan (indeks ponderal) dan TKG. Kenaikan TKO akan menghambat laju pertubuhan dan reproduksi. Sedangkan hubungan osmolaritas gonad dengan IKG linier bersifat linier positif dimana kenaikan osmolaritas gonad akan diikuti dengan bertambahnya nilai IKG.

\section{UCAPAN TERIMA KASIH}

Ucapan terimakasih disampaikan kepada pihak-pihak yang telah membantu dalam menganalisis sampel ataupun menalaah isi materi sehingga artikel ini dapat terbit. Prof. Dr. Ir. Agus Hartoko, M.Sc dan Dra. Niniek Widyorini, MS yang telah memberikan kritik dan saran bagi kesempurnaan tulisan ini. Pengelola laboratorium hidrologi yang telah membantu dalam menyedialan alat Automatic Osmometer Roebling beserta reagennya untuk pengukuran osmolaritas.

\section{DAFTAR PUSTAKA}

Aisyah., K, Kasim., S, Triharyuni, dan Husnah. 2018. Estimasi

Status Stok Sumberdaya Kepiting Bakau (Scylla serrata) di Estuari Mahakam, Kalimantan Timur. Bawal Widya Riset Perikanan Tangkap. 10(3) : 217225.doi:http://dx.doi.org/10.15578/bawal.9.3.2017. 207-213
Anggoro, S. 1992. Efek Osmotik Berbagai Tingkatan Salinitas Media terhadap Daya Tetas Telur dan Vitalitas Larva Udang Windu, Panaeus monodon. Fabricius. Disertasi. Program Pasca Sarjana Institut Pertanian Bogor.

2000. Pola Osmotik dan Kerja Enzim Na-KUdang

Windu (Panaeus mododon Fab) pada Berbagai Fase Molting. Aquaculture Indonesia 1(2) : 15-21.

Anggoro, S, dan K. Nakamura. 2005. Osmoregullation of Kuruma Prawn (Penaeus Japonicus. Bull. Kagoshima, 2(3) : 14-19.

Anggoro, F. Purwanti., W.T Taufani dan N. Nakamura. 2018. Effect of Osmotic Shocks on Sodium Regulation and Na-K-ATPase Activity of Pasific White Shrimp (Litopenaeus vannamei Boone, 1931). Pakistan Academy of Sciences. 55(1):15-19.

Bidawi, B. M., D. Desrita, dan Y. Yunafsi. Hubungan Panjang Berat dan Faktor Kondisi Ikan Belodok (Famili: Gobiidae) pada Ekosistem Mangrove di Desa Pulau Sembilan Kabupaten Langkat Provinsi Sumatera Utara. Jurnal Ilmu-ilmu Perairan, Pesisisr dan Perikanan. 6(3) : 228-234. doi : 10.13170/depik.6.3.7029

Darwasito, S., H. J. Sinjai, dan I. Wahyuni. 2015. Tingkat Perkembangan Gonad, Kualitas Telur, dan Ketahanan Hidup Larva Ikan Nila (Oreochromus niloticus) Berdasarkan Perbedaan Sainitas. Jurnal LPPM Bidang Sains dan Teknologi Akuakultur. 2(2) : 86-94

Ditjen P2HP. 2011. P2HP Dalam Angka 2010. Direktorat Jenderal Pengolahan dan Pemasaran Hasil Perikanan. Kementerian Kelautan dan Perikanan. Jakarta

Effendie, M.I. 2002. Biologi Perikanan. Yogyakarta : Yayasan Dwi Sari

Fachrul, M. F. 2007. Metode Sampling Bioekologi. Jakarta : Bumi Aksara.

FAO (Food and Agriculture of the United Nations). 2011. The State of World Fisheries and Aquaculture. FAO, Rome.

Habibi., Sukendi dan N. Aryani. 2013. Kematangan Gonad Ikan Sepat Mutiara (Trichogaster Lerri Blkr) dengan Pemberian Pakan yang Berbeda. Jurnal Akuakultur Rawa Indonesia. 1(2) : 127-134

Hasan, M. I. 2002. Pokok-pokok Materi Metodologi Penelitian dan Aplikasinya. Ghalia Indonesia. Jakarta

Katiandagho, B. 2014. Analisis Fluktuasi Parameter Kualitas Air terhadap Aktifitas Molting Kepiting Bakau (Scylla serrata). Jurnal Ilmiah Agribisnis dan Perikanan. 7(2) : 21-25. doi : 10.29239/j.agrikan.7.2.21-25

Hidayat, T., H.Y. Yusuf., Nuruddin, dan A.R.P, Pane. 2017. Parameter Populasi Kepiting Bakau (Scylla serrata) di Perairan Pasaman Barat. Bawal. 9(3) : 207-213. doi:http://dx.doi.org/10.15578/bawal.9.3.2017.207$\underline{213}$

Novian, D. S., Diana, dan Sutrisno, A. 2013. Kebiasaan Makanan dan Osmoregulasi sebagai Landasan

C Copyright by Saintek Perikanan: Indonesian Journal of Fisheries Science and Technology, ISSN : 1858-4748 
Domestikasi Keong Macan (Babylonia spirata I). Journal of Management of Aquatic Resources. 2(2) : 249-257

Pamungkas,W. 2012. Aktivitas Osmoregulasi, Respons Pertumbuhan, dan Energetic Cost pada Ikan yang Dipelihara pada Salinitas yang Bersalinitas. Media Akuakultur. 7(1) : 44-51

Purnama, M. F., La, O. A. A, dan Haslianti. 2016. Pengaruh Induksi Autotomi pada Kepiting Bakau (Scylla serrata, Scylla tranquebarica, Scylla paramamosain) terhadap Sintasan Moulting dan Pertumbuhan di Tambak Rakyat Kelurahan Anggoeya Kendari Sulawesi Tenggara. Jurnal Teknologi Hasil Perikanan. 5(2) : 190-203
Puryono, S., S. Anggoro., Suryanti dan I. S Anwar. 2019. Pengelolaan Pesisir dan Laut Berbasis Ekosistem. Semarang : Undip Press

Rachmawati, D., J. Hutabarat dan S. Anggoro. 2012. Pengaruh Salinitas Berbeda terhadap Pertumbuhan Keong Macan (Babylonia spirata L) pada Proses Domestikasi. Ilmu Kelautan. 17(3):141-147.

Rahardja, M.F., Sjafei, D.S., Affandi, dan Sulistiyono. 2011. Ikhtiologi. Bandung : CV Lubuk Agung.

Sentosa, A. S, dan A. R, Syam. 2011. Sebaran Temporal Kepiting Bakau (Scylla serrata) di Perairan Pantai Mayangan, Kabupaten Subang, Jawa Barat. Jurnal Perikanan.8(1):35-43.

doi:https://doi.org/10.22146/jfs.3060 